"Mircea cel Batran" Naval Academy Scientific Bulletin, Volume XX - 2017 - Issue 1

The journal is indexed in: PROQUEST / DOAJ / Crossref / EBSCOhost / INDEX COPERNICUS / DRJI / OAJI I

JOURNAL INDEX I I2OR / SCIENCE LIBRARY INDEX / Google Scholar I Academic Keys/ ROAD Open Access I

Academic Resources / Scientific Indexing Services / SCIPIO / JIFACTOR

\title{
ASPECTS REGARDING THE DIMENSIONING OF ELECTRICAL INSTALLATIONS USING POWER ENGINEERING SOFTWARE
}

\author{
Georgică SLĂMNOIU ${ }^{1}$ \\ Nicolae JULA ${ }^{2}$ \\ Victor BĂDĂNĂU ${ }^{3}$ \\ ${ }^{1}$ Captain (N) Assoc. prof. dr. eng. Research Center for Navy, Constanța, România \\ ${ }^{2}$ Prof. dr. eng. Military Technical Academy, București, România \\ ${ }^{3}$ Junior researcher eng. Research Center for Navy, Constanța, România
}

Abstract: On T22 frigates, the quality of the oil used in gearboxes is provided by centrifugal separators. In the operation cycle of those separators, it is necessary to preheat the oil in limited conditions of temperature and flow. Currently, the preheating process is designed to be carried out by air preheaters. The paper shows the technical solution in order to replace air preheating with electrical heating. Also it provides a comparison between the direct computation results with the Power Analytics' DesignBase Software calculations done for the studied case.

\section{Introduction}

Onboard of frigates, due to the incoming difficulties of air preheating process it is necessary to replace air preheating system of the gearbox oil.

The technological prescriptions impose a minimum $60^{\circ} \mathrm{C}$ temperature of the oil at the centrifugal separators admission and it has to be done in minimum $8 \mathrm{~h}$ for the whole quantity of the oil.

The calculations needed in order to provide the technical solution will be done directly, using as well the Power Analytics' DesignBase Software which will play an important role in validating the technical solution.

The DesignBase Software is an efficient program for the steady-state analysis, with advanced display options. The software is based on advanced computational algorithms incorporating technical solutions applicable to complex systems. The DesignBase results include:

- Phase voltage;

- Reactive power, voltage drop, power factor;

- Active and reactive power circulations;

- Generated power, power consumption, power loses;

- Overvoltage;

- Overcurrent.

Technical requirements for the heater design In order to determine the installed power of the electrical heater for the OM100 oil type there was used the relation according to [15]:

$$
P=\frac{V \cdot \rho \cdot c_{p} \cdot\left(t_{2}-t_{1}\right) \cdot 1,2}{860 \cdot T}
$$

where:

$$
\begin{aligned}
& V=\text { preheated oil } \\
& \text { in }\left[\mathrm{dm}^{3}\right] \\
& \rho=\text { oil density, in }\left[\mathrm{kg} / \mathrm{dm}^{3}\right] \\
& c_{p}=\text { thermal coefficient, in }\left[\mathrm{kcal} / \mathrm{kg}^{\circ} \mathrm{C}\right] \\
& t_{1}=\text { initial temperature of the oil, in }\left[{ }^{\circ} \mathrm{C}\right] \\
& t_{2}=\text { final temperature of the oil, in }\left[{ }^{\circ} \mathrm{C}\right] \\
& T=\text { preheating time, in }[\mathrm{h}]
\end{aligned}
$$

For the following technical data, corresponding to a gearbox, thus:

$$
\begin{array}{ll}
- & V=9600 \mathrm{dm}^{3} \\
- & c_{p}=0,45 \mathrm{kcal} / \mathrm{kg}^{\circ} \mathrm{C} \text { for the OM100 } \\
& \text { oil type; } \\
-\quad & \rho=0,869 \mathrm{~kg} / \mathrm{dm}^{3} \\
- & t_{1}=9^{\circ} \mathrm{C} \\
- & t_{2}=60^{\circ} \mathrm{C} \\
- & T=8 \mathrm{~h}
\end{array}
$$

has resulted an installed power of $24 \mathrm{~kW}$ at the network voltage of $3 \times 440 \mathrm{~V}, 60 \mathrm{~Hz}$ corresponding to the onboard power system of the ship. For the OM33 oil type for axial lines and pitch propeller systems has been chosen an electric heater with an $8 \mathrm{~kW}$ installed power. The electrical installation provides the power for two electric heaters of $24 k W$, one for each gearbox, and an $8 k W$ electric heater for axial lines and pitch propeller systems.

These electric heaters act as part of the existing oil separators. 
"Mircea cel Batran" Naval Academy Scientific Bulletin, Volume XX - 2017 - Issue 1

The journal is indexed in: PROQUEST / DOAJ / Crossref / EBSCOhost / INDEX COPERNICUS / DRJI / OAJI I JOURNAL INDEX I I2OR / SCIENCE LIBRARY INDEX / Google Scholar I Academic Keys/ ROAD Open Access I Academic Resources / Scientific Indexing Services / SCIPIO / JIFACTOR

Giving the vital importance of oil preparation for gearboxes, axial lines and pitch propeller, on which the ship operation depends, it was chosen electrical heaters with naval certification, manufactured by a specialized company - Alfa Laval, respectively the EHS 71 type shown in figure
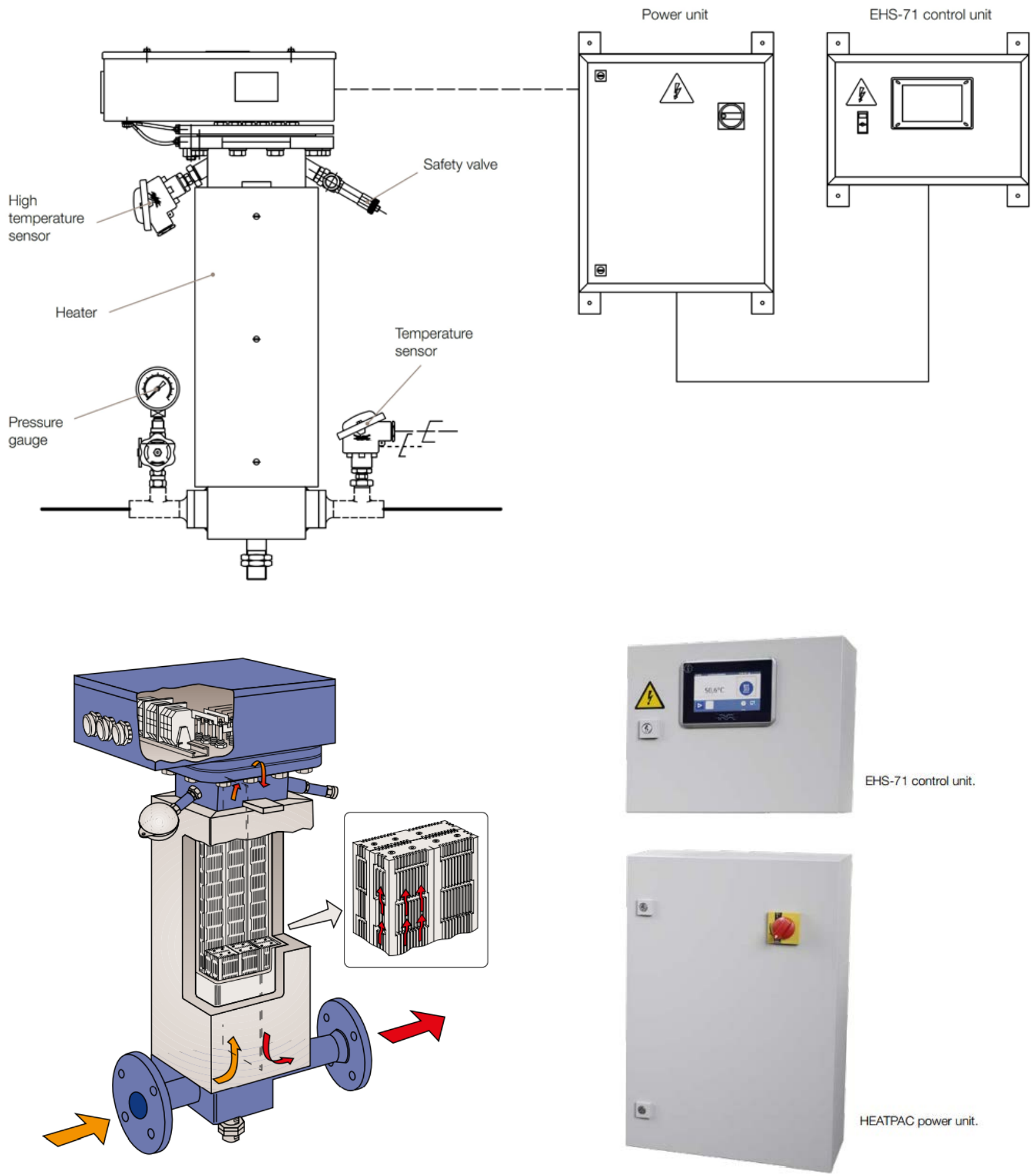

Figure 1. Principle diagram for HEATPAC system

\section{Technical solution for power supply}

Oil heaters power supply is done by three current ways from EHP panel. The EHP panel is powered from the main distribution panel of the ship -
EDC, which is powered either from the Diesel generator onboard the ship or from quay. 
"Mircea cel Batran" Naval Academy Scientific Bulletin, Volume XX - 2017 - Issue 1

The journal is indexed in: PROQUEST / DOAJ / Crossref / EBSCOhost / INDEX COPERNICUS / DRJI / OAJI I

JOURNAL INDEX I I2OR / SCIENCE LIBRARY INDEX / Google Scholar I Academic Keys/ ROAD Open Access I

Academic Resources / Scientific Indexing Services / SCIPIO / JIFACTOR

Due to the $3 \times 400 \mathrm{~V} / 50 \mathrm{~Hz}$ terrestrial power system functioning, for frigates, whose electro energetic system comply with STANAG 1008 conditions, thus $3 \times 440 \mathrm{~V} / 60 \mathrm{~Hz}$, at the quay there is a corresponding transformer and converter station.
The power supply structure of the EHP electric panel, from onboard or from quay power supply is shown in the single line diagram from the figure 2.

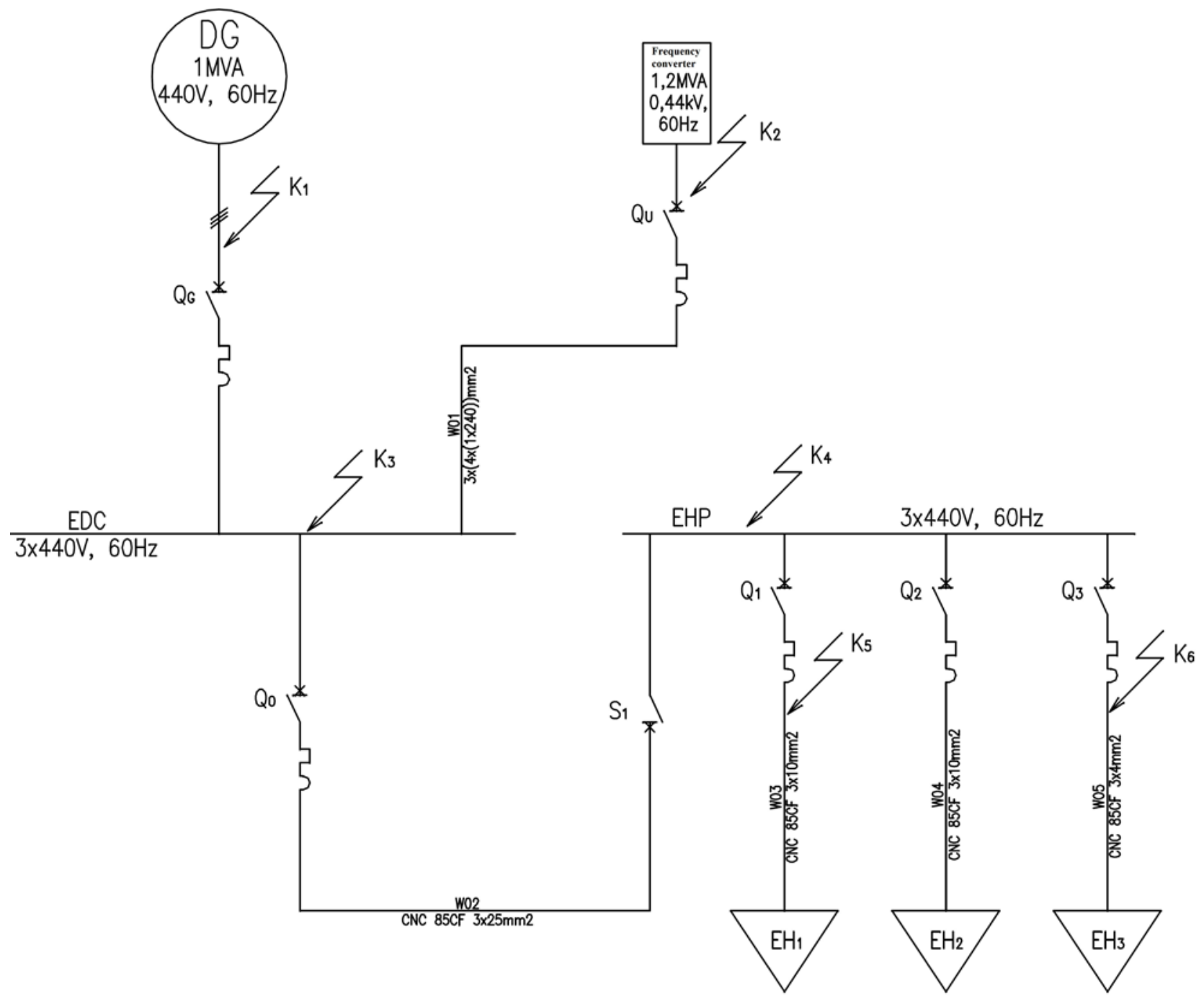

Figure 2. Single line diagram for EHP power supply.

\section{Sizing and protection of the circuits}

In order to design the electrical installation, it is considered an absorbed power $P_{c}=47,6 \mathrm{~kW}$ and a maximum absorbed current $I_{b}=65,8 \mathrm{~A}$, which have been determined using a demand coefficient $k_{c}=0,85$ and a power factor $\cos \varphi=0,95$, according to [2], table 1.3 for resistive consumers with continuous load regime. The resulted values of the currents and voltage drop for cable sizing are shown in table 1 . 
"Mircea cel Batran" Naval Academy Scientific Bulletin, Volume XX - 2017 - Issue 1

The journal is indexed in: PROQUEST / DOAJ / Crossref / EBSCOhost / INDEX COPERNICUS / DRJI / OAJI I JOURNAL INDEX I I2OR / SCIENCE LIBRARY INDEX / Google Scholar I Academic Keys/ ROAD Open Access I Academic Resources / Scientific Indexing Services / SCIPIO / JIFACTOR

Table 1. Circuits design results

\begin{tabular}{|c|c|c|c|c|c|c|}
\hline $\begin{array}{c}\text { Load } \\
\text { name } \\
\text { (cables) }\end{array}$ & Power & $\begin{array}{l}\text { Demanded } \\
\text { current }\end{array}$ & $\begin{array}{l}\text { Cross } \\
\text { sectional } \\
\text { area }\end{array}$ & $\begin{array}{c}\text { Maximum } \\
\text { permissibl } \\
\text { e current }\end{array}$ & $\begin{array}{c}\text { Maximum } \\
\text { corrected } \\
\text { permissible } \\
\text { current }\end{array}$ & Voltage drop \\
\hline Formula & $P_{c}=k_{c} P_{i}$ & $I_{b}=\frac{P_{c}}{\sqrt{3} U_{l} \cos \varphi}$ & $\begin{array}{c}S\left[\mathrm{~mm}^{2}\right], \\
\text { according } \\
\text { to [12], p. } \\
2.13 .2\end{array}$ & $\begin{array}{c}\quad I_{z}[A], \\
\text { according } \\
\text { to [12], p. } \\
2.13 .2\end{array}$ & $\begin{array}{l}I_{z}^{\prime}=k_{1} k_{2} I_{z}, \\
\text { where } \\
k_{1}=0,7 ; \\
k_{2}=1,06 \\
\text { according to } \\
{[12],} \\
2.13 .2 .3 ; \\
2.13 .2 .5\end{array}$ & $\begin{array}{l}\Delta U=\frac{P_{2} R_{l}+Q_{2} X_{l}}{U_{n}}[V] \\
\Delta U \%=\frac{\Delta U}{U_{n}} \cdot 100[\%], \\
\text { according to [9], G27 }\end{array}$ \\
\hline $\begin{array}{l}\text { EHP } \\
\text { (W02) }\end{array}$ & $47,6 \mathrm{~kW}$ & $65,8 \mathrm{~A}$ & $25 \mathrm{~mm}^{2}$ & $120 A$ & $89 \mathrm{~A}$ & $0,5 \%$ \\
\hline $\begin{array}{c}\text { EH1 } \\
\text { (W03) }\end{array}$ & $24 k W$ & 33,15 A & $10 \mathrm{~mm}^{2}$ & $67 A$ & $49,71 A$ & $0,84 \%$ \\
\hline $\begin{array}{l}\text { EH2 } \\
\text { (W04) }\end{array}$ & $24 k W$ & 33,15 A & $10 \mathrm{~mm}^{2}$ & $67 A$ & $49,71 A$ & $0,84 \%$ \\
\hline $\begin{array}{l}\text { EH3 } \\
\text { (W05) }\end{array}$ & $8 k W$ & $11 \mathrm{~A}$ & $4 \mathrm{~mm}^{2}$ & $38 A$ & $28 \mathrm{~A}$ & $0,7 \%$ \\
\hline
\end{tabular}

In order to choose proper protective devices, it is necessary to determine short-circuit currents for different measuring points of the installation, according to figure 2 . The main condition that has to be meet is: the breaking capacity of the protective device has to be greater than the shortcircuit current in the nearby of the device mounting position.

Short-circuit currents are determined for threephase short-circuit, without earthing, for which was drawn the equivalent diagram with resistances and reactances of the circuit elements as shown in figure 3 , from the power source to the fault spot, in physical units.
The values for resistances and reactances, as well as the computation formula are presented in table 2.

Computations are made for two practical situations:

- onboard power supply (using as power source the vessel's Diesel generator)

- $\quad$ onshore power supply, using an system of three frequency converters of $400 \mathrm{kVA}$ 0,4 kV / $50 \mathrm{~Hz} ; 0,44 k \mathrm{kV} / 60 \mathrm{~Hz}$ each, treated in the equivalent diagram as a power source (UPS). 
"Mircea cel Batran" Naval Academy Scientific Bulletin, Volume XX - 2017 - Issue 1

The journal is indexed in: PROQUEST / DOAJ / Crossref / EBSCOhost / INDEX COPERNICUS / DRJI / OAJI I JOURNAL INDEX I I2OR / SCIENCE LIBRARY INDEX / Google Scholar I Academic Keys/ ROAD Open Access I Academic Resources / Scientific Indexing Services / SCIPIO / JIFACTOR

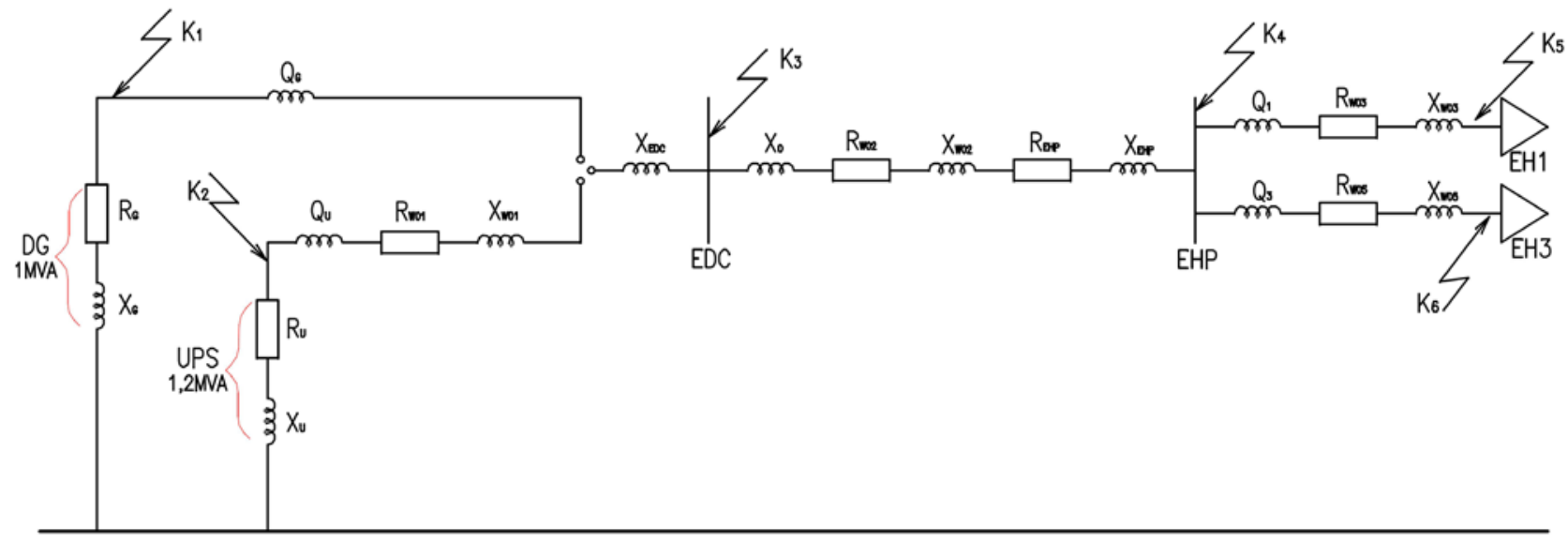

Figure 3. Electrical equivalent diagram, in physical units

Table 2. Resistance and reactance values results

\begin{tabular}{|c|c|c|c|c|}
\hline \multirow{2}{*}{ Circuit element } & \multicolumn{2}{|c|}{ DesignBase computations } & \multicolumn{2}{c|}{ Direct computations } \\
\cline { 2 - 5 } & Resistance $[\Omega]$ & Reactance $[\Omega]$ & Resistance $[\Omega]$ & Reactance $[\Omega]$ \\
\hline DG & 0,1500 & 0,0065 & 0,0035 & 0,0240 \\
\hline$Q_{G}$ & 0,0000 & 0,0001 & 0,0000 & 0,0002 \\
\hline UPS & 0,9990 & 0,4344 & 0,1766 & 0,1765 \\
\hline$Q_{U}$ & 0,0000 & 0,0002 & 0,0000 & 0,0002 \\
\hline Cable W01 & 0,0009 & 0,0007 & 0,0023 & 0,0024 \\
\hline Bare EDC & 0,0000 & 0,0005 & 0,0000 & 0,0005 \\
\hline$Q_{0}$ & 0,0020 & 0,0006 & 0,0000 & 0,0002 \\
\hline Cable W02 & 0,0043 & 0,0033 & 0,0192 & 0,0029 \\
\hline Bare EHP & 0,0000 & 0,0002 & 0,0006 & 0,0002 \\
\hline$Q_{1}$ & 0,0024 & 0,0000 & 0,0000 & 0,0002 \\
\hline Cable W03 & 0,0042 & 0,0033 & 0,0675 & 0,0029 \\
\hline$Q_{3}$ & 0,0070 & 0,0000 & 0,0000 & 0,0002 \\
\hline Cable W05 & 0,0043 & 0,0033 & 0,1688 & 0,0029 \\
\hline
\end{tabular}

The resulted values of the short-circuit currents for both power supply variants are presented in table 3. It can be observed that for onboard power supply, the short-circuit currents are greater than those resulted in the case of onshore power supply through frequency converters.

Frequency converters were treated as a power source of 1,2MVA with short-circuit powers, physically far inferior to a synchronous generator. The situation is atypical compared with supplied military vessels of autochthonous production with an power system at $50 \mathrm{~Hz}$ frequency, for which, in case of onshore power supply the short-circuit currents are slightly bigger than for the case of onboard power supply, due to the greater shortcircuit power of the onshore power source.

The short-circuit currents calculation was also made in Design Base 3.0 software in order to compare the obtained results through direct computation with those resulted from the program, according to table 3 . In the software computation, the characteristics of circuit elements are from its own library. By comparison, the results of both computation methods are similar. 
"Mircea cel Batran" Naval Academy Scientific Bulletin, Volume XX - 2017 - Issue 1

The journal is indexed in: PROQUEST / DOAJ / Crossref / EBSCOhost / INDEX COPERNICUS / DRJI / OAJI I JOURNAL INDEX I I2OR / SCIENCE LIBRARY INDEX / Google Scholar I Academic Keys/ ROAD Open Access I Academic Resources / Scientific Indexing Services / SCIPIO I JIFACTOR

Table 3. Short-circuit currents values.

\begin{tabular}{|c|c|c|c|c|c|c|c|c|c|c|}
\hline \multicolumn{11}{|c|}{ DesignBase results } \\
\hline & \multicolumn{5}{|c|}{ Powered from the vessel's DG } & \multicolumn{5}{|c|}{ Powered from an onshore source } \\
\hline $\begin{array}{l}\text { Short- } \\
\text { circuit } \\
\text { location }\end{array}$ & $\begin{array}{l}\text { DG } \\
\left(k_{1}\right)\end{array}$ & $\begin{array}{l}\text { EDC } \\
\left(k_{3}\right)\end{array}$ & $\begin{array}{l}\text { EHP } \\
\left(k_{4}\right)\end{array}$ & $\begin{array}{l}\mathrm{EH} 1 \\
\left(k_{5}\right)\end{array}$ & $\begin{array}{l}\mathrm{EH} 3 \\
\left(k_{6}\right)\end{array}$ & $\begin{array}{l}\text { UPS } \\
\left(k_{2}\right)\end{array}$ & $\begin{array}{l}\text { EDC } \\
\left(k_{3}\right)\end{array}$ & $\begin{array}{l}\text { EHP } \\
\left(k_{4}\right)\end{array}$ & $\begin{array}{l}\mathrm{EH} 1 \\
\left(k_{5}\right)\end{array}$ & $\begin{array}{l}\mathrm{EH} 3 \\
\left(k_{6}\right)\end{array}$ \\
\hline$I_{s c}$ & 11,02 & 10,9 & 9,1 & 7,64 & 7,18 & 1,57 & 1,57 & 1,51 & 1,45 & 1,41 \\
\hline \multicolumn{11}{|c|}{ Direct computations results } \\
\hline & \multicolumn{5}{|c|}{ Powered from the vessel's DG } & \multicolumn{5}{|c|}{ Powered from an onshore source } \\
\hline $\begin{array}{l}\text { Short- } \\
\text { circuit } \\
\text { location }\end{array}$ & $\begin{array}{l}\mathrm{DG} \\
\left(k_{1}\right)\end{array}$ & $\begin{array}{l}\text { EDC } \\
\left(k_{3}\right)\end{array}$ & $\begin{array}{l}\text { EHP } \\
\left(k_{4}\right)\end{array}$ & $\begin{array}{l}\mathrm{EH} 1 \\
\left(k_{5}\right)\end{array}$ & $\begin{array}{l}\mathrm{EH} 3 \\
\left(k_{6}\right)\end{array}$ & $\begin{array}{l}\text { UPS } \\
\left(k_{2}\right)\end{array}$ & $\begin{array}{l}\text { EDC } \\
\left(k_{3}\right)\end{array}$ & $\begin{array}{l}\text { EHP } \\
\left(k_{4}\right)\end{array}$ & $\begin{array}{l}\mathrm{EH} 1 \\
\left(k_{5}\right)\end{array}$ & $\begin{array}{l}\mathrm{EH} 3 \\
\left(k_{6}\right)\end{array}$ \\
\hline$I_{s c}$ & 11,52 & 11,24 & 7,7 & 2,91 & 1,43 & 1,57 & 1,54 & 1,49 & 1,3 & 1 \\
\hline
\end{tabular}

Power Analytics' DesignBase Software allows the determination of the voltage drop for each element of the circuit using the Advanced Power Flow module.
Thus, a comparison can be made between the results obtained for both power supply methods, verifying the admissible limits according to [12]. The results are presented in the table 4.

Table 4. Voltage drops- DesignBase results

\begin{tabular}{|c|c|c|c|c|c|c|c|c|c|c|}
\hline & \multicolumn{4}{|c|}{ Powered from the vessel's DG } & \multicolumn{5}{c|}{ Powered from an onshore source } \\
\hline $\begin{array}{c}\text { Circuit } \\
\text { element }\end{array}$ & DG & EDC & EHP & EH1 & EH3 & UPS & EDC & EHP & EH1 & EH3 \\
\hline$\Delta U[\%]$ & 0,00 & 0,00 & 0,19 & 0,25 & 0,21 & 0,00 & 0,03 & 0,22 & 0,27 & 0,23 \\
\hline
\end{tabular}

\section{Conclusions}

- When powered from onboard power source, the electrical network from onboard is of TT type, with benefits related to electrical safety and continuity of supply.

When powered from the quay, the onboard electrical network at $3 \times 400 \mathrm{~V} / 50 \mathrm{~Hz}$ becomes a TT network, in the same time the $3 \times 230 \mathrm{~V} / 50 \mathrm{~Hz}$ network continues to be an IT network because it uses step-down transformers.

- In terms of the choice of automatic circuit breakers, switching from the onboard to the onshore power supply requires the express verification of the short-circuit braking capacity, condition which if not complied, lead to thermal damage and finally to fire in the electrical network.

- This verification is mandatory and it implies an exact calculation of the short-circuit currents since, usually the short-circuit power of the quay network, which belongs to National Power System, is far 
"Mircea cel Batran" Naval Academy Scientific Bulletin, Volume XX - 2017 - Issue 1

The journal is indexed in: PROQUEST / DOAJ / Crossref / EBSCOhost / INDEX COPERNICUS / DRJI / OAJI /

JOURNAL INDEX I I2OR / SCIENCE LIBRARY INDEX / Google Scholar I Academic Keys/ ROAD Open Access I

Academic Resources / Scientific Indexing Services / SCIPIO / JIFACTOR

superior to the short-circuit power of the limited power plant from onboard the vessel.

Because the connection conditions to the quay network are not exactly known (or changes with location), there are adopted precautionary measures, thus the circuit breakers are connected in series with high breaking capacity fuses.

It is also the case of the main power supply panel EDC from the onboard of T22 frigates.

- Thus it is very helpful to use specialized computer programs (such as DesignBase) which can validate the results of short circuit currents computations as well as to display the power and current flow in the circuits network.

- In this case, as presented in the paper, the situation is reversed to the general case, i.e. the shortcircuit current values are lower when using the quay power supply instead of the onboard power source.

The exception is determined by the fact that onboard the T22 frigates the network is at $3 \times 440 \mathrm{~V} / 60 \mathrm{~Hz}$ (NATO standard STANAG 1008) and the quay network is at $3 \times 400 \mathrm{~V} / 50 \mathrm{~Hz}$.

Thus, it was necessary to connect to a transformer and conversion station from $50 \mathrm{~Hz}$ to $60 \mathrm{~Hz}$. As a result, the short-circuit powers are limited by the power of the frequency converters, with lower performances for overloads compared to the onboard synchronous generator.

\section{Bibliography}

[1] Product catalogues, Schneider Electric, 2015.

[2] Dan Comșa, Silviu Darie, Virgil Maier, Mircea Chindriș, Proiectarea instalațiilor electrice industriale, Editura Didactică și Pedagogică, București 1983.

[3] Electrical installation guide, Schneider Electric, 2016.

[4] Emil Racoți, Dimensionarea rețelelor electrice cu ajutorul tabelelor și nomogramelor, Editura Tehnică, București 1988.

[5] Gh. Chiriță, C. Alexe, Cartea instalatorului electrician, Editura Tehnică, Bucuresti 1971.

[6] I. Ignat, G.C. Popovici, Rețele electrice de joasă tensiune, Editura MatrixRom, București 2003.

[7] 17/2011 Normativ pentru proiectarea, execuția și exploatarea instalațiilor electrice aferente clădirilor.

[8] IEC 60909-0, Prima ediție 2001.

[9] Manualul instalațiilor electrice, Schneider Electric, 2007.

[10] Normativ PE 134-2/96, Privind metodologia de calcul al curenților de scurtcircuit în rețele electrice cu tensiune sub $1 \mathrm{kV}$.

[11] Normativ PE 134-95, Privind metodologia de calcul al curenților de scurtcircuit în rețele electrice cu tensiune peste $1 \mathrm{kV}$.

[12] Registrul naval român, vol. 4.

[13] Siemens, Memoratorul inginerului electrician, Editura tehnică, București 1971.

[14] Silviu Darie, Ioan Vădan, Producerea, transportul și distribuția energiei electrice. Instalații pentru transportul și distribuția energiei electrice, Editura U.T. Pres, Cluj-Napoca, 2003

\section{Internet sources:}

[15] nph-processheaters.com

[16] alfalaval.com 